\title{
Does a Monetary Union protect against foreign shocks? An assessment of Latin American integration using a Bayesian VAR
}

\author{
Jean-Pierre Allegret* \\ and \\ Alain Sand-Zantman*
}

\begin{abstract}
:
This paper analyses the monetary consequences of the Latin-American trade integration process. We consider a sample of five countries -Argentina, Brazil, Chile, Mexico and Uruguay- spanning the period 1991-2007. The main question raised pertains to the feasibility of a monetary union between L.A. economies. To this end, we study whether this set of countries is characterized by business cycle synchronization with the occurrence of common shocks, a strong similarity in the adjustment process and the convergence of policy responses. We focus especially our attention on two points. First, we try to determine to what extent international disturbances influence the domestic business cycles through trade and/or financial channels. Second, we analyze the impact of the adoption of different exchange rate regimes on the countries' responses to shocks. All these features are the main issues in the literature relative to regional integration and OCA process.
\end{abstract}

Key-words : Business Cycles, OCA, Bayesian VAR, Latin American Countries

JEL Classification: C32, E32, F42.

\footnotetext{
- University of Lyon, Lyon, F-69003, France; CNRS, UMR 5824, GATE, Ecully, F-69130, France; ENS LSH, Lyon, F-69007, France ; Centre Leon Berard, Lyon, F-69003, France. allegret@gate.cnrs.fr

- Corresponding author, OFCE-FNSP, Paris, F-75007, and University of Lyon, Lyon, F-69003, France; CNRS, UMR 5824, GATE, Ecully, F-69130, France; ENS LSH, Lyon, F-69007, France ; Centre Leon Berard, Lyon, F-69003, France. a.sand@ens-1sh.fr
} 


\section{Introduction}

The 1990s were characterized by an intensification of Regional Trade Agreements in the Americas. The main agreements are the Southern Common Market (MERCOSUR) -signed in 1991 between Argentina, Brazil, Paraguay, Uruguay (and more recently Venezuela), with Bolivia, Chili, Peru, Colombia, and Ecuador as associates- and the North American Free Trade Area (NAFTA) -signed in 1994 between Canada, Mexico and the United States with more and more agreements with other Latin American countries (LACs) (Chili, Peru, Ecuador... $)^{1}$. Since 1994, a Free Trade Area Agreement for the Americas has been discussed, as an extension of the NAFTA. In the spirit of Eichengreen and Taylor (2004), this paper analyses the monetary consequences of this trade integration process. We consider a sample of five countries -Argentina, Brazil, Chile, Mexico and Uruguay- that account for some 70 per cent of the region's GDP spanning the period 1991-Q1 - 2007-Q1. The paper assembles a quarterly dataset (see Appendix 1 for data sources) including both main international macroeconomic variables -such as the GDP of the Group of seven countries and the world commodities prices index- and main domestic variables -such as GDP and real exchange rates. In addition, we consider variables based on the literature dedicated to the sudden stop problem (Calvo et al., 2004): the Emerging Economy spread index and the foreign exchange reserves.

The main question raised in this paper refers to the feasibility of a monetary union between these countries. To this end, we study whether this set of countries is characterized by business cycle synchronization with the occurrence of common shocks, a strong similarity in the adjustment process and the convergence of policy responses. We focus especially our attention on two points. First, we try to determine to what extent international disturbances influence the domestic business cycles through trade and/or financial channels. Second, we analyze the impact of the adoption of different exchange rate regimes on the countries' responses to shocks. As shown in appendix 2, studied countries adopted very different exchange rate regimes over the 1991-2007 period. While at the beginning, the set of countries ranged from hard peg (Argentine currency board) to intermediate regimes, at the end, it exhibited a clear switch toward floating regimes.

The present paper is linked to two separate strands of literature. The first one, dedicated to the debate of monetary union versus dollarization, includes numerous papers analyzing the

\footnotetext{
1. We can also mention the CARICOM (Caribbean Community and Common Market, 1973), the CACM (Centre America Common Market, 1960), CAN (Andean Community, 1969)
} 
situation of Central and Latin American countries relative to the United States ${ }^{2}$. Empirical studies suggest that dollarization is not an obvious solution, even for Mexico. For instance, Karas (2003) finds that Mexican output fluctuations have been negatively correlated with the American fluctuations. According to Hallwood et al (2006), Brazilian, Chilean and Uruguayan permanent shocks are correlated with Argentina suggesting that a monetary union could be a better solution than dollarization. The second strand of literature analyzes the sources of business cycles fluctuations in emerging countries. Two lessons from this literature are especially interesting for our purpose. On the one hand, a large body of studies suggests that the main source of fluctuations originated from external factors. Aiolfi et al (2006) considering a sample of four $\mathrm{LACs}^{3}$ - identify the presence of a common regional factor. Taking into account the weak intra-regional trade integration, this result suggests that the regional business cycle (major turning points are common to the four countries) is driven by external variables and common external shocks. On the other hand, the financial channel based on international interest rates for instance- seems more significant than the trade channel in understanding the influence of external shocks on domestic business cycle fluctuations in $\mathrm{LACs}^{4}$.

The remainder of this paper is organized as follows. Section 2 explains the methodology adopted in this paper and founded on Bayesian structural VAR models. Section 3 presents the macroeconomic variables included in the VAR, the results and the policy implications. Section 4 concludes.

\section{Methodology of the Study}

This paper rests on two important methodological points: on the one hand, we propose a way to take into account the structural breaks affecting LACs over the period and, on the other hand, we use a Bayesian structural VAR.

\subsection{Non-Stationarity and Structural Breaks: the Special Case of Emerging Economies}

The emerging economies case -and more especially LACs- is not the simplest for time series methodology. Indeed, this group of countries exhibits numerous structural breaks -e.g. the end of hyperinflation and the dramatic increase in commodities prices after 2000- and/or changes in policy regimes such as the exchange rate regimes collapses that result in new

\footnotetext{
${ }^{2}$. See for instance Salvatore (2001), Corbo (2001), Alesina et al. (2003), Karas (2003), Larrain and Tavares (2003), Hallwood et al. (2006), and Allegret and Sand-Zantman (2007 and 2008).

${ }^{3}$. Argentina, Brazil, Chile, and Mexico over the period 1870-2004. See also Canova (2005) and Maćkowiak (2007).

${ }^{4}$. See Ahmed (2003), Canova (2005), and Österholm and Zettelmeyer (2007).
} 
monetary policy frameworks. Since the seminal works of Nelson and Plosser (1982), most macroeconomic time series in level are considered unit root process. On the same sample, Nelson and Plosser, Perron (1989) challenged this interpretation, indicating that most macroeconomic variables are trend stationary, coupled with structural breaks. Looking at the Latin-American macroeconomic time series, we assert the same hypothesis: the econometricians had to take into account structural breaks due to non-random external as well as internal shocks and policy regime changes. The right way to deal with this question consists (in the Perron procedure) of testing for unit roots in the presence of structural change at a known date. If the date of the break is uncertain, other tests are available (Vogelsang and Perron, 1998, or Zivot and Andrews, 2002) on common softwares. However, as shown in Le Bihan (2004) all these procedures are powerless when the number and the date of the break are unknown. Overall, the combination of a short sample and multiple breaks weaken the break diagnosis compared to the following unit root test.

We choose a rougher but probably more secure method. First we identify the noticeable breaks of the figures ${ }^{5}$ as being the well-known historical ones (due for instance to balance of payments crisis or policy regime switches): the results are displayed in Appendix 3. As particular (and generally deterministic) events, these breaks can hardly be considered as the N.I.D. stochastic innovations of a random walk. Second, in order to stationarize the macroeconomic series, we clean them from the various deterministic trends and intercept leaps, using simple time trends and dummy variables. We finish with a common A.D.F. test, finding all series stationary. Thus, we can exclude any cointegration relationship but a VAR in level is an available alternative to the VECM one. We choose a recursive semi-structural approach for a VAR in level of the detrended series.

\subsection{A Bayesian Structural VAR}

Undeniably, the sample is short and the number of variables fairly high. In this case, Litterman $(1979,1984)$ suggests specifying blurred restrictions on the mean and variance of the coefficients instead of brutal "ad hoc" exclusions. As Doan (2007) concludes, "in a vector autoregression, we must concern ourselves not only with the lags of the dependent variables, but also with the lags of the other endogenous variables. Because of the stability conditions, we have some pretty good information about the size of lag coefficients in a simple autoregression. However, it's not so clear what the sizes of the coefficients on the other variables should be, and these depend, in part, on the relative scales of the variables

\footnotetext{
5. To this end, we use Chow tests.
} 
involved". As indicated by Canova (2007), priors on the mean and variance of the variable allow one to deal with over parametrization.

The choice of priors is the simplest one: overweighting the first lags of endogenous variables of each equation. Although a fine tuning prior is unrealistic, a deeper investigation is necessary to provide a better assessment of the consequences of innovations but it could be time-wasting.

In the same way, this version uses a semi structural BVAR. Using a Bayesian justifies once more avoiding structural orthogonalization: Canova (2007) shows that the combination of Bayesian methods and structural hypothesis is not the simplest one, particularly for economies characterised by a succession of policy regimes.

\section{The Model and the Results}

\subsection{Variables selection}

Our variables are based on the traditional ones for VARs analyzing external shocks and macroeconomic packages in open economies and on the literature dedicated to the sudden stop problem.

Each domestic VAR includes three external variables. As real external shocks, we consider (i) the Gross Domestic Product for the G7 (noted LGDPG7) and (ii) the world commodities prices excluding oil (noted WCPNO). Our choice to exclude oil from our commodities prices index is due to the fact that some LACs (for instance Brazil and Mexico) are both producers and consumers of oil.

The Emerging Economy spread index of J.P. Morgan $(E M B I)^{6}$ accounts for the international financial shock. Many studies choose US interest rates or international interest rates -such as LIBOR- to estimate the impact of external financial shocks on emerging markets. We prefer to use the $E M B I$ in order to disentangle monetary policy shocks and financial shocks. Further, over our sample period, the EMBI does not seem significantly influenced by LIBOR, confirming the González-Rozada and Levy-Yeyati (2005) results which show that spreads are

\footnotetext{
${ }^{6}$ We merged two time series: the EMBI for the period 1991Q1-1997Q4 and the EMBI+ from 1998Q1. As indicated in Cunningham (1999), the main differences between these indices are (i) the number of financial instruments embodied (the EMBI tracks returns and spreads on Brady Bonds and some other restructured sovereign debts, the EMBI+ tracks returns on a wider range of instruments), (ii) the number of countries (11 for the EMBI, 16 for the EMBI+). However, in both indices the weight of the LAC is very important (respectively 83.8\% and 70.2\%). Amongst the LAC, both Argentina and Brazil account for $47.6 \%$ of the EMBI+. In 1999, J.P.Morgan released a new index, the EMBIG (for "global") embodying more countries (27) and more titles. In this last index, LAC decreased to $61.5 \%$.
} 
determined by global factors ${ }^{7}$. Uribe and Yue (2006) analyze the respective influence of US interest rates and EMBI shocks on the macroeconomic fluctuations in a sample of seven emerging countries covering the period 1994-2001. An important finding is that EMBI shocks exacerbate the US interest rate shocks, implying a strong macroeconomic volatility in the studied emerging countries.

For the domestic variables, we took the foreign reserves (FOREX) as proxy for the balance of payments, the gross domestic product $(G D P)$, the consumption prices index $(C P I)$, the nominal money market interest rate $(R)$ and the real effective exchange rate $^{8}(E R)$.

Calvo et al. (2004) stress that sudden stop episodes are characterized by both international reserves losses and sharp current account reversals. The former increases the country's vulnerability to shocks while the latter leads to output and employment contractions. Quarterly balance of payments data are not reliable and subject to sizable revisions. As a result, our VARs do not include current account data. As a proxy for sudden stop problems, we choose to include central bank's foreign exchange reserves. In order to test the robustness of the results, we substitute the deseasonalized exports-imports ratio to FOREX. This ratio represents a proxy for the intertemporal constraint of the current account: a decrease in capital inflows imposes the reduction of absorption in order to increase exports and decrease imports. Interestingly, the results do not change significantly. As a result, we prefer to consider only the FOREX variables in order to avoid some interpretation difficulties owing to the fact that the ratio obeys in part competitive factors, and not exclusively financial factors.

\subsection{The Model}

The model is tested separately for each LAC. The number of lags -two in each model- has been selected using the common set of criteria and tests. As the inverse roots of the AR polynomial lie in the unit circle, VARs satisfy the stability condition.

The following order of Choleski factorization is deduced from our theoretical interpretation of the contemporary correlation matrix of the reduced form residuals of each country model and from block exogeneity Wald tests.

\footnotetext{
7. We perform different experiments in our VARs: first, we include both $L I B O R$ and $E M B I$; second, we include only $L I B O R$. Results do not significantly change. Granger causality tests do not exhibit relations between $E M B I$ and $L I B O R$.

${ }^{8}$. An increase (decrease) in the real exchange rate means real depreciation (appreciation).
} 

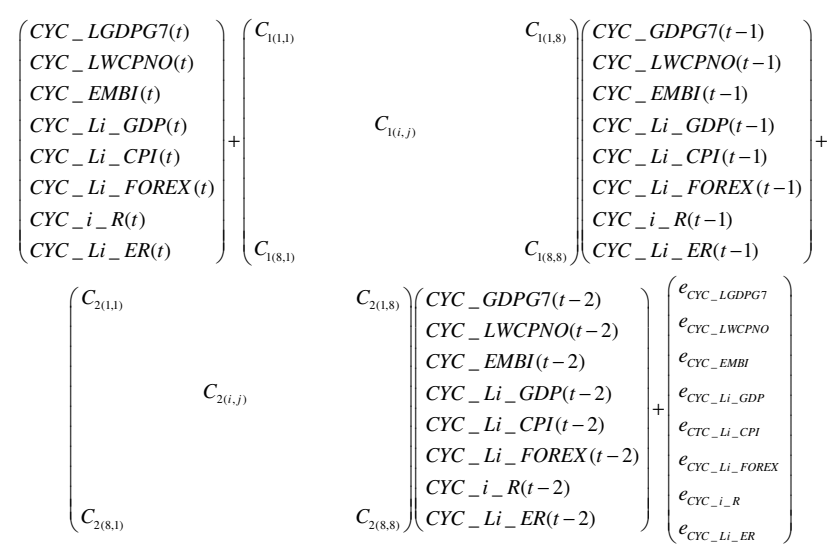

with = $A$ for Argentina, $B$ for Brazil, $C$ for Chile, $M$ for Mexico, and $U$ for Uruguay.

External variables are considered the most exogenous. We assume that real external variables are predetermined relative to external financial ones. In addition, we consider that the GDP of the G7 countries exerts an influence on commodities prices through a demand effect. For domestic variables, different plausible orders have been experimented. They do not significantly change the results.

\subsection{Econometric findings}

Using this framework, we combine the impulse response functions (tracing out the time paths of the effects of pure shocks on the set of variables, see Appendix 4), and the forecast error variance decomposition (indicating the proportion of the movements in a sequence due to its own shocks versus to the other variables, see Appendix 5). This allows us to assess the degree of similarity in the reactions of macroeconomic variables to shocks amongst the set of countries. At the same time, we get a first outline of the specific-versus common- economic consequences of shocks in terms of spontaneous adjustments, as well as in terms of policy responses ${ }^{9}$.

\section{Responses of domestic variables to external shocks: is transmission real or financial?}

In all studied countries, GDP fluctuations are significantly influenced by foreign variables. Our results show that in Argentina, Brazil, and Chile foreign variables explain at least $29 \%$ of the GDP variance decompositions after 16 quarters. In Mexico and Uruguay, the shares are $16.1 \%$ and 20\% respectively. Above all, no domestic variables -except GDP itself- exert a greater influence than foreign innovations in all countries.

As expected, GDP increases after a shock on GDPG7. The positive influence of GDPG7 means that improvement (vs degradation) of the business cycle in G7 countries can result in

\footnotetext{
${ }^{9}$. All results mentioned in the text but not displayed are available upon request to the authors.
} 
an increase (vs slowdown) of growth in LACs. The weak influence of GDPG7 in Brazil rests on the fact that this economy is a more closed economy relative to other studied countries. In all countries except Uruguay, GDP increases after a shock on commodities prices (WCPNO) confirming the importance of commodities in LACs' business cycles. Not only are contemporaneous responses significant and positive but they continue to have significant persistent effects.

A large body of empirical literature dedicated to the business cycle in LACs stresses that growth in these economies follows international capital flows. More precisely, these studies suggest that the behavior of capital inflows is pro-cyclical: they tend to increase when growth in LACs improves. As a result, we can expect a significant influence of EMBI shocks on GDP during the period on our sample of countries. We find that GDP decreases after a shock on $E M B I$. The magnitude of the GDP response is important in Argentina and Uruguay, and to a lesser extent in Mexico. The Chilean case is particularly interesting. While Chilean spread stayed substantially below EMBI+ or Latin American spread over the period, its GDP responds negatively to $E M B I$ shock. Even if the response is weakly significant from a statistical point of view, this result suggests that this type of shock is global, i.e. affects all countries, even economies benefiting from low idiosyncratic risk premiums.

Our findings confirm Allegret and Sand-Zantman (2008) with regard to the specific sensitivity of Argentina to EMBI shock. During the first half of the 90s, Argentina was one of the main borrowers in international capital markets enjoying very favorable financing conditions, while in the second half of the decade the economy, it suffered from a sudden-stop of capital inflows. In addition, the monetary policy constraints due to the currency board limited the ability of authorities to react in the face of EMBI shocks, inducing strong and ample macroeconomic variability.

Overall, LACs differ according to the respective influence of trade and financial channels. Two groups of countries can thus be distinguished: in the first one, including Brazil, Chile and Mexico, trade channels predominate and in the second group, composed of Argentina and Uruguay, financial channels exert the main influence on GDP variances. In addition, as suggested by the Chilean experience, international financial shocks have a global nature.

The relevance of the sudden stop

Two main points characterize the sudden stop literature. First, external factors exert a decisive influence on capital inflows into emerging markets. Second, depreciation results in contractionary output in emerging markets whereas it produces traditional expansionist effects 
in industrialized countries (Calvo and Reinhart, 2001). Indeed, exchange rate crises in emerging markets are followed by a sudden stop to capital inflows. These countries suffer from reserve losses and severe reversal in the current account deficit. Such reversal is based on a major decline in aggregates.

In order to assess the relevance of the sudden stop literature, we determine what variables foreign or domestic, real or financial- exert the main influence on FOREX included in our VARs as a proxy of international capital flows. The theoretical prediction is that international financial shocks, here the EMBI shock- are the main variables influencing FOREX in our five countries. In addition, we analyze the influence of FOREX on other domestic variables. According to the sudden stop literature, a negative shock on FOREX must lead to a contraction in GDP.

Interestingly, from the sudden stop literature standpoint, FOREX is influenced by international variables, and more specifically by financial variables. Thus, the international financial shock produces the expected effects when significant. An increase in the spread meaning degradation in the financial conditions for emerging countries- leads to a decrease in FOREX in Argentina and Brazil, and to a lesser extent in Chile after 3 quarters. Variance decompositions support the significant influence of EMBI on the behavior of FOREX. In Argentina, Brazil and Chile, EMBI innovations explain $15.4 \% ; 8.2 \%$ and $7.8 \%$ of the FOREX variance. In each of the three countries, $E M B I$ is its main explanatory variable. In addition, we find that FOREX does not respond to interest shocks. In other words, increasing domestic interest rates is insufficient to induce the accumulation of international reserves. Such a result is in accordance with the sudden stop literature that suggests that FOREX responds more to global shocks than domestic ones.

A FOREX shock generates few domestic fluctuations. This deceptive result does not necessarily contradict the sudden stop literature. Indeed, as stressed by Izquierdo et al. (2007), episodes of financial volatility tend to produce effects on real variables only in short-run. A plausible explanation is that the more significant effects of sudden stop on domestic variables are absorbed extremely rapidly, within one or two quarters. VAR models in levels are not well-equipped to detect these types of changes. Indeed, such models analyze the responses of macroeconomic variables to shocks of standard magnitude (usually one standard deviation), and not to unusual disturbances proper to crisis episodes. In addition, the main purpose of VAR models is not to identify crisis events. Crisis episodes are relevant only if they lead to structural breaks in the studied macroeconomic series. 
Finally, we see that GDP decreases in the aftermath of the real depreciation. Three competing explanations are advanced in this paper. First, real depreciations may be indicative of economic activity slowdown in the medium-term. This interpretation is not confirmed by the behavior of the FOREX variable. Indeed, while a negative response of FOREX to a real depreciation is expected -due to capital outflows - we observe in fact insignificant reactions of this variable. Real exchange rates innovations do not explain a significant share of FOREX variance in the five countries. Second, an alternative explanation of the negative relationship between GDP and real depreciations rests on the presence of negative balance sheet effects. The inability to borrow abroad in local currency -the so-called original sin- and the dollarization of the domestic economy can induce currency mismatch in the balance sheets of public and private agents. Using the degree of dollarization estimated by Reinhart, Rogoff and Savastano (2003), such explanation seems relevant only in Argentina and Uruguay ${ }^{10}$. Finally, a last explanation, most likely relevant in countries with low degrees of dollarization (Brazil, Chile and Mexico) suggests that the negative correlation between GDP and real exchange rate depreciations stems from shocks that induce both a real depreciation and a decline in GDP. Negative terms of trade shocks result in such negative correlation.

\section{Credibility matters}

Given the importance of the inflationary history of numerous LACs, the responses of interest rates to innovations in consumption prices are particularly significant. Responses of interest rates are especially important to consider because they allow us to discriminate between credible and less credible countries. In Argentina and Chile, interest rates decrease or do not react after a CPI shock. In these two countries, inflation expectations are well anchored by the monetary regime in place in each country. Recall that from 1991 to 2001, Argentina had experienced a currency board arrangement while Chile had adopted an inflation targeting framework since 1991. In countries with soft pegs and a monetary policy not based on an inflation targeting framework -as Brazil, Mexico and Uruguay- inflation expectations are imperfectly anchored. So, in such countries, shocks on prices induce higher fluctuations. Variance decompositions exhibit a clear picture. In Argentina and Chile, CPI innovations explain a mild or marginal share of the interest rates variances, respectively 8.7 and 0.2 contemporaneously; and 12.8 and 1.8 after 16 quarters, while in Brazil the respective shares

\footnotetext{
${ }^{10}$. According to the authors, Argentina and Brazil belong to Type I dollarization in which domestic and external liability dollarization co-exist; Uruguay is a dollarized economy of Type II where dollarization is predominantly of a domestic nature; and Chile and Mexico are Type III dollarization: the main part of debt in foreign currencies is external. Degrees of dollarization differ among our countries: high in Argentina (index 20 on a scale that goes from 0 to 30) and Uruguay (21), but weak in Brazil (7), Chile (7) and Mexico (5).
} 
are $70.9 \%$ and $68.2 \%$. In this latter country interest rate innovations explain only a weak share of the $C P I$ variance ( $0 \%$ contemporaneously and $10.2 \%$ after 16 quarters). As expected, $C P I$ shocks lead to real exchange rate appreciations. In comparison with countries enjoying imperfect monetary credibility, the responses of the real exchange rates are short-lived in Argentina and Chile.

\subsection{Policy recommendations}

Recently, a set of publications displayed a critical balance of stabilization and structural reforms in emerging economies, and particularly in the LA ones. In line with a large stream of critics on the "Washington-Consensus-style" reforms, the contribution of Hausmann, Rodrik, and Velasco (2005) rejects the idea of a unified paradigm altogether, advocating idiosyncratic policies adjusted to specific features and constraints. But these conclusions are not shared by all observers: for Zettelmeyer (2006) the unusually high macroeconomic volatility of the last decades is a common feature of the main part of LACs, in spite of recent improvements in macroeconomic management and structural reforms. Singh (2004) explains this vulnerability by a combination of domestic and foreign factors. From the domestic side, he listed mainly fiscal rigidities, weak institutions, low productivity, strong inequalities and unemployment or insufficient market competition. The consequences are excess demand, inflation, financial instability, external imbalance and unofficial dollarization.

These characteristics limit the scope for macroeconomic management faced with external shocks (unstable terms of trade or sudden stops of capital flows). Further, from an optimal currency area perspective such volatility could hinder regional integration, increasing the costs of policy coordination.

Our outcomes are in line with this evidence, entailing two main policy implications. First, foreign variables bring on a near-common business cycle in the region: LACs tend to react similarly to the same foreign shocks whatever the exchange rate regime. Above all, we do not detect significant adverse asymmetric external shocks among our studied countries even if different degrees and types of dollarization imply that LACs are more or less sensitive to international financial shocks. In other words, most external shocks are common to LACs and characterize global shocks. Contrary to several studies, we also find that real channels seem as important as financial ones in explaining the influence of foreign variables on domestic ones in our sample. Faced with such a common fate, an important question is to determine to what extent a monetary union may insulate against such shocks. Using probit panel regressions to investigate whether countries forming a monetary union have a lower occurrence of sudden 
stop episodes and of current account reversal episodes, and whether they are better able to absorb external shocks, Edwards (2006) finds that belonging to a currency union has not lowered the probability of a sudden stop or a current account reversal, and external shocks have been amplified in currency union countries.

Another way to face adverse foreign shocks is to favour more exchange rate flexibility in order to use them as bumper. Besides, since 2002 LACs exhibit a clear shift to more flexible exchange rates. Obviously, it leads to higher bilateral exchange rate volatility and as such, it may be unfavourable to economic and financial integration. But this stage could be a transitory process, necessary to put the house in order if during this adjustment, LACs strengthen policy coordination. Institutional frameworks for this purpose already exist: for instance, in the Mercosur case, the Protocol of Ushuaia (1997) established a permanent structure dedicated to coordination. Targets and procedures intended to allow the convergence of public deficits and the debt ratios were defined. A high-level macroeconomic Group of surveillance equivalent to the Ecofin council in the European Union was created. In 2002 the project of the Monetary Institute for Mercosur was launched. Clearly, policy coordination improves the ability of LACs to respond to external shocks, but coordination does not suffice: LACs may create a regional monetary fund in order to use it in case of adverse external shocks. The boom in commodity prices -that began in 2002- is an exceptional opportunity to favor the accumulation of foreign exchange reserves dedicated to this fund. The main point is that such a regional fund, already envisaged in East and South-East Asia, may function as a mutual insurance mechanism ${ }^{11}$. But is such a mechanism optimal in case of symmetric shocks? It is dubious. First because international financial markets could better allocate risks between countries in which the business cycles are asymmetric than in a set of countries sharing the same business cycle (except perhaps in case of high transactions costs differentials) (see Obstfeld, 1995) ${ }^{12}$. Second because the strong correlation between country risk ratings and risk of contagion effects in regional zones as the Mercosur can be explain by the imperfect information prevailing in international financial market: each time one of the partners -and particularly one of the largest- was overtaken by a crisis, the most prevalent reaction amongst the other members was a fear of spillovers. As noted by Machinea and Rozenwurcel (2005), the usual response of policy makers in other countries has been to send

\footnotetext{
${ }^{11}$ A detailed analysis of insurance mechanisms for LACs in beyond the scope of this paper. For an overview,_see World Bank (2007).

${ }^{12}$ As noted by the World Bank, the problem overcomes the LAC area as for any mutual found or market insurance "the diversification margin is relatively limited in light of the high correlation of credit risk within the emerging market class, limiting the potential size of credible coverage and increasing its costs", (World Bank, 2007: 22-23).
} 
out signal that differentiates them from their distressed neighbor in an effort to influence the mainstream perception on financial markets ${ }^{13}$. Obviously, the contagion issue is linked with the credibility one.

The question of domestic credibility is the second policy issue of our paper, in particular monetary policy credibility. Indeed, our estimates do not allow us to distinguish countries according to their exchange rate regimes. A better distinction to analyze responses to similar shocks is based on the different degrees of credibility. As is well-known, LACs have a long history of inflation resulting in fragile inflation expectations anchors. Since the beginning of 1990s, credibility gains have been impressive in LACs. The main point is that, as suggested by the endogenous OCA approach, differences in authorities' credibility may represent an impediment to the convergence targets. To favor economic policy convergence, it seems important that LACs adopt a similar anchor. Shock asymmetry between the LACs and the United States implies that the US dollar is not a good candidate. As a result, LACs need an alternative anchor to dollarization to avoid "the perennial misuse of monetary policy" by their central banks (Corbo, 2001: 246). Trade diversity from a geographic point of view may favor a peg to a common currency basket. But such a peg lacks transparency. An alternative solution, suggested by Eichengreen and Taylor (2004 and more recently by Rose (2007), would be for LACs to adopt a similar inflation target in the conduct of their monetary policy. Brazil, Chile and Mexico have already adopted such a monetary framework. Inflation targeting provides two main advantages that are especially important for LACs. First, central banks with inflation targeting tend to strengthen their credibility. Second, not only is such monetary regime more viable than fixed or intermediate exchange rate arrangements, but it also favors exchange rate stability. In other words, it seems possible to decrease bilateral exchange rate volatility without an explicit coordination mechanism that is very difficult to implement in the area. A similar monetary framework -less ambitious relative to policy coordination- may lead to less volatility. Recent evidence exhibits mixed results. Brazil, Chile and Mexico have experienced better inflation performance than Argentina and Uruguay, two countries that have adopted a monetary aggregate target in the aftermath of their exchange rate regime collapse. From this standpoint, inflation targeting has improved economic policy credibility in significant LACS. But at the same time, Argentine and Uruguayan experiences suggest that the authorities of these two countries follow a de facto managed floating regime

\footnotetext{
${ }^{13}$ And the authors explain: "Their reason for doing so is that the adverse effects to be expected in the short run have been of such magnitude, and the decision-making horizon for governmental and private-sector actors has shortened to such a point that the ratio between the perceived costs and benefits of integration has grown drastically worse".
} 
in which their exchange rates are confined within a very narrow range. As a consequence, these multiples objectives damage the credibility of their central banks leading to a slowdown of their inflation convergence towards the Brazilian and the Mexican indexes (the best performers). Such a policy does not favor economic policy convergence between LACS. Credibility gains may also favor the financial structure convergence among LACs. As our results above suggest, the lack of financial structure convergence -mainly due to different degrees and types of dollarization- is an additional factor explaining the slow economic policy convergence. Indeed, dollarized countries such as Argentina and Uruguay are especially sensitive to specific shocks (external financial shocks inducing real exchange rates depreciations) limiting their ability to converge with other LACs from an economic policy point of view. More credible monetary policies may lead to a decrease in the degree of dollarization, reducing the currency mismatch and the external financial vulnerabilities of LACs. Indeed, as stressed by Levy-Yeyati (2006), dollarization is a rational response of economic agents to expectations of high and volatile inflation. Recent trends are promising. Except Uruguay, and to a lesser extent Argentina, all studied countries have significantly reduced their currency mismatch since 2001 (IMF, 2007: 35). Cowan et al (2006) show that not only domestic public debt follows a significant dedollarization trend, but also that some LACs are now able to borrow in domestic currency in international capital markets decreasing the magnitude of the original $\sin ^{14}$.

\section{Concluding remarks}

Our results converge to indicate that LACs are influenced by foreign variables, either real ones for Brazil, Chile, and Mexico, or financial ones for Argentina and Uruguay. Our attempt to test the relevance of the sudden stop literature leads us to mixed conclusions. If our proxy of international capital inflows -the FOREX variables- is significantly explained by foreign financial variables, the analysis of domestic variable responses to FOREX shocks does not follow the predictions of common knowledge.

We need to be cautious in the interpretation of our results. On the one hand, our analysis does not take into account the real convergence process. Camarero et al. (2006) study such a process by considering productivity differences among Mercosur countries. Over the period 1960-1999, the authors find the presence of a "Mercosur club" meaning a real convergence process. Regional integration has played a significant role in this process. As suggested by

\footnotetext{
${ }^{14}$ According to the authors, the size of the economy and the degree of development of domestic financial markets exert an influence on this trend. This latter factor is in part linked with macroeconomic policy credibility.
} 
Camarero et al. (2006), real convergence raises the question of the level of the exchange rate chosen by each country at the entering date in the monetary union. Indeed, as most LACs know, during a catching-up process, their equilibrium exchange rates may change. On the other hand, our VAR models ignore regional interdependencies despite the fact that spillovers within the region exert a significant influence on the LACs' business cycles. For instance, Uruguayan economic activity depends mainly on Argentine and Brazilian business cycles. In addition, some empirical studies suggest that financial market interdependencies may explain exchange rates movements within the region ${ }^{15}$.

\section{References}

Ahmed S. (2003), "Sources of Economic Fluctuations in Latin America and Implications for Choice of Exchange Rate Regimes", Journal of Development Economics, 72, 81-202.

Aiolfi M., L. Catão and A. Timmermann (2006), "Common Factors in Latin America's Business Cycles", IMF Working Paper, WP/06/49, February.

Alesina A., R. Barro and S. Tenreyro (2003), “Optimal Currency Areas”. In Mark Gertler and Kenneth Rogoff (eds). NBER Macroeconomic Annual 2002. Cambridge, Mass: The MIT Press.

Allegret J.P. and A. Sand-Zantman (2007), "Disentangling Business Cycles and Macroeconomic Policy in Mercosur: a VAR and Unobserved Components Model Approaches", Journal of Economic Integration, 22(3), 482-514.

Allegret J.P. and A. Sand-Zantman (2008), "Modeling the Impact of Real and Financial Shocks on Mercosur: the Role of the Exchange Rate Regime", Open Economies Review, forthcoming.

Calvo G. and Reinhart C.M. (2001), "Fixing for Your Life", in S. Collins and D. Rodrik (eds), Brookings Trade Forum 2000, Brookings Institution, Washington DC, 1-39.

Calvo G.A., A. Izquierdo and L.-F. Mejia (2004), "On the Empirics of Sudden Stops: The Relevance of Balance-Sheet Effects", NBER Working Paper Series, ${ }^{\circ} 10520$, May.

Camarero M., R.G. Flôres Jr. and C.R. Tamarit (2006), "Monetary Union and Productivity Differences in Mercosur Countries", Journal of Policy Modeling, 28, 53-66.

Canova F. (2005), "The Transmission of US Shocks to Latin America", Journal of Applied Econometrics, 20, 229-251.

Canova F. (2007), Methods for Applied Macroeconomic Research, Princeton University Press.

Corbo V. (2001), "Is It Time for a Common Currency for the Americas?", Journal of Policy Modeling, 23, 241-248.

Cowan K., E.,Levy-Yeyati, U. Panizza and F. Sturzenegger (2006), "Sovereign Debt in the Americas: New Data and Stylized Facts", Central Bank of Chile Working Papers, n³71, August.

Cunningham A. (1999), "Emerging Economy Spread Indices and Financial Stability", Financial Stability Review, Issue 7, November, 115-127.

Doan T.A. (2007), User's GuideRats version 7, Estima.

Edwards S. (2006), "Monetary Unions, External Shocks and Economic Performance: a Latin American Perspective, NBER Working Paper Series, ${ }^{\circ} 12229$, May.

\footnotetext{
${ }^{15}$. For the Chilean peso, see IMF (2002), Chile: Selected Issues, IMF Country Report, nº2/163, August.
} 
Eichengreen B. and A. Taylor (2004), "The Monetary Consequences of a Free Trade Area of the Americas", in A. Estevadeordal, D. Rodrik, A. Taylor and A. Velasco (eds.) Integrating the Americas: FTAA and Beyond, New York: Harvard University Press.

González-Rozada M and E Levy-Yeyati (2005) "Global Factors and Emerging Market Spreads", CIF Working Paper $\mathrm{N}^{\circ} 07 / 2005$, December.

Hallwood P., I. Marsh and J. Scheibe (2006), "An Assessment of the Case for Monetary Union or Official Dollarization in Five Latin American Countries", Emerging Markets Review, 7(1), 52-66.

Haussmann R., D. Rodrik and A. Velasco (2005), "Growth Diagnostics", John F. Kennedy School of Government, Harvard University (Cambridge, Massachussets). http://ksghome.harvard.edu/ drodrik/barcelonafinalmarch2005.pdf.

International Monetary Fund (2007), Regional Economic Outlook: Western Hemisphere, November, Washington D.C.

Izquierdo A., R. Romero and E. Talvi (2007), "Business Cycles in Latin America: The Role of External Factors", Mimeo, September.

Karras G. (2003), "The prospect of Dollarization: are the Americas an Optimum Currency Area?", in C. Tsoukis, G. Agiomirgianakis and T. Biswas (eds.) Aspects of Globalisation : Macroeconomic and Capital Market Linkages in the Integrated World Economy, Dordrecht: Kluwer Academic Publishers, 183-199.

Larrain F. and J. Tavares (2003), "Regional Currencies Versus Dollarization: Options for Asia and the Americas", Policy Reform, 6, 35-49.

Le Bihan H. (2004), "Tests de rupture : une application au PIB tendanciel français", Économie et Prévision, 2004/2 - n $163,133-154$.

Levy-Yeyati E. (2006), "Financial Dollarization: Evaluating the Consequences", Economic Policy, 21(45), 61-118.

Litterman R.B. (1979), “Techniques of Forecasting Using Vector Autoregressions”, P.H.D., Working Paper 115, F.R.B. of Minneapolis.

Litterman R.B. (1984) “The Cost of Intermediate Targeting”, Working Paper 254, F.R.B. of Minneapolis.

Machinea J.L. and G. Rozenwurcel (2005), "Macroeconomic Coordination in Latin America: Does It Have a Future?" Informes y Estudios Especiales $\mathrm{n}^{\circ} 15$, United Nation, CEPAL, Santiago, Chile, December.

Maćkowiak B. (2007), "External Shocks, U.S. Monetary Policy and Macroeconomic Fluctuations in Emerging Markets", Journal of Monetary Economics, 54, 2512-2520.

Nelson C. and C. Plosser (1982), "Trends and Random Walks in Macroeconomic Time Series: Some Evidence and Implications". Journal of Monetary Economics, 10. 139-162.

Obstfeld M. (1995), "International Capital Mobility in the 1990s", in P.B. Kenen (ed.) Understanding Interdependance; The Macroeconomics of the Open Economy, Princeton, N.J.: Princeton University Press, 201-261.

Österholm P. and J. Zettelmeyer (2007), "The Effect of External Conditions on Growth in Latin America", IMF Working Paper, WP/07/176.

Perron P. (1989), "The Great Crash, the Oil Price Shock, and the Unit Root Hypothesis", Econometrica, vol. 57(6), 1361-1401

Reinhart C., K. Rogoff and M.A. Savastano (2003), “Addicted to Dollars”, NBER Working Papers Series, $n^{\circ} 10015$, October.

Rose A.K. (2007), "A Stable International Monetary System Emerges: Bretton Woods Revisited", Journal of International Money and Finance, 26: 663-681.

Salvatore D. (2001), "Which Countries in the Americas should Dollarize?", Journal of Policy Modeling, 23, 347-355. 
Singh S. (2004) "Latin America: Sustaining Reforms and Growth" Remarks by Anoop Director of the Western Hemisphere Department International Monetary Fund Delivered at investors' meetings in Lima, Peru at the time of the 45th Annual Meeting of the InterAmerican Development Bank Lima, March 27-28, 2004

Uribe M. and V. Yue (2006), "Country Spreads and Emerging Countries: Who Drives Whom?", Journal of International Economics, 69, 6-36.

Vogelsang T. and P. Perron (1998), "Additional Tests for a Unit Root Allowing for a Break in the Trend Function at an Unknown Time", International Economic Review, 39(4), 1073-1100.

World Bank (2007), Country Insurance: Reducing Systemic Vulnerabilities in LAC, Document of the World Bank, November 15, Washington D.C.

Zettelmeyer, J. (2006), "Growth and Reforms in Latin America: A survey of Facts and Arguments", IMF Working Paper, WP/06/210.

Zivot, E. and Andrews, D. (2002), "Further Evidence on the Great Crash, the Oil Price Shock and the Unit Root Hypothesis", Journal of Business and Economic Statistics, 20, 25-44. 


\section{Appendix 1 Data and Sources}

\begin{tabular}{|l|l|}
\hline Data & Sources \\
\hline GDP Group of Seven & OECD \\
\hline World commodities prices excluding oil & IMF, International Financial Statistics \\
\hline EMBI & $\begin{array}{l}\text { Ministry of Economy and Production of the Republic of Argentina } \\
\text { (http://www.mecon.gov.ar/peconomica/basehome/infoeco_ing.html) }\end{array}$ \\
\hline GDP & $\begin{array}{l}\text { IPEA (http://www.ipea.gov.br) for Argentina, Brazil, Chile, and } \\
\text { Mexico } \\
\text { Central Bank of the Republic of Uruguay }\end{array}$ \\
\hline Consumption Prices Index & IMF, International Financial Statistics \\
\hline Foreign Exchange Reserves & IMF, International Financial Statistics \\
\hline Money Market Interest Rates & $\begin{array}{l}\text { IMF, International Financial Statistics for Argentina, Brazil, } \\
\text { Mexico, and Uruguay } \\
\text { Central Bank of Chile for Chile }\end{array}$ \\
\hline Real Exchange rates & $\begin{array}{l}\text { IMF, International Financial Statistics for Chile and Uruguay } \\
\text { Central Bank of Argentina for Argentina } \\
\text { IPEA for Brazil } \\
\text { OECD for Mexico }\end{array}$ \\
\hline
\end{tabular}

\section{Appendix 2 Exchange Rate Regimes in the Selected Latin American Countries}

\begin{tabular}{|c|c|c|c|c|c|}
\hline Countries & Year/Month & Exchange rate regime & Countries & Year/Month & Exchange rate regime \\
\hline \multirow[t]{5}{*}{ Argentina } & 1990-M1 & Independently floating & Brazil (cont.) & 1998-M4 & Forward-looking crawling peg \\
\hline & 1991-M1 & Horizontal band & & 1999-M1 & Independently floating \\
\hline & 1991-M3 & Currency board & Chile & 1990-M1 & Backward-looking crawling peg \\
\hline & $2001 \mathrm{M} 12$ & Managed floating & & 1998-M9 & Forward-looking crawling peg \\
\hline & 2004M11 & Other tightly managed floating & & 1999-M9 & Independently floating \\
\hline \multirow[t]{5}{*}{ Brazil } & 1990-M1 & Backward-looking crawling peg & Mexico & 1990-M1 & Forward-looking crawling peg \\
\hline & 1990-M3 & Managed floating & & 1994-M12 & Independently floating \\
\hline & 1991-M5 & Backward-looking crawling peg & Uruguay & 1990_M1 & Backward-looking crawling peg \\
\hline & 1994-M7 & Tightly managed & & 1992_M1 & Forward-looking crawling peg \\
\hline & 1995-M3 & Backward-looking crawling peg & & 2002-M6 & Independently floating \\
\hline
\end{tabular}

Source: from A. Bubula and I. Ötker-Robe's Database. 


\section{Appendix 3: Structural breaks}

\section{International Variables}

The Commodity Prices and the EMBI are both marked by a structural break from the last quarter of 2001, due to the simultaneity of a Commodity Prices hike and a decrease of EMBI.

\section{Domestic Variables}

\section{Argentina :}

Except the economic mayhem at the beginning of the $90 \mathrm{~s}$, the only structural break (intercepts and trends) comes from the exchange rate collapse of 2002. Attacks on Foreign Reserves are perceptible since 2001, with the unhooking of both the Foreign Reserves and the Interest Rate. About one year later, it hits the Exchange Rate, the GDP and the CPI.

Let us note in particular that the Tequila contagion (after the Mexican Crisis of 1994-95) is not obviously perceptible.

\section{Brazil:}

Two well known events are worthy of note: the Real Plan in 1994 and the currency crash of 1998-99. But in 2002, the Argentinean crisis contagion and the political uncertainty of the presidential election weighed on the Exchange Rate. Except this point, we had to introduce a break for 1994 in the $C P I$, the Foreign Reserves, and the Interest Rate (but curiously neither for the real Exchange Rate nor the GDP). The 1998-1999 crisis hit significantly the Exchange Rate and the Foreign Reserves (but neither the CPI nor the interest rate).

\section{Chili:}

The Chilean economy is particularly sensible to international financial mayhem: so, the main break is due to the Asian Crisis, in 1997, hitting all the variables except the GDP. But the uncertainty following the Argentinean crisis is perceptible as much on the Exchange Rate as on the Interest Rate.

\section{Mexico:}

Obviously, the Currency Crash of 1994-95 hit all the real and nominal variables, beginning in the last quarter of 1994 with the Foreign Reserves, the Interest Rate, and then hurting the Exchange Rate, the CPI, and the GDP in 1995.

\section{Uruguay:}

The introduction of structural breaks in the case of Uruguay could be discussed. Although some shocks are obviously non-random ones, the high frequency of macro-fluctuations in the Uruguayan case makes break detection difficult. However, two shocks are clearly perceptible, with a break on the GDP (due to the Brazilian Currency Crash at the end of 1998) and a break on all the macroeconomic variables (except the CPI) after the Argentinean Crisis of 2002. 
Appendix 4 Forecast Error Impulse Responses of One Standard Deviation (Innovations $\pm 2 \mathrm{SE}$ )

1- Are International Transmission Real or Financial?

Figures display for each country the responses of GDP to GDPG7, WPNCO and EMBI shocks respectively.

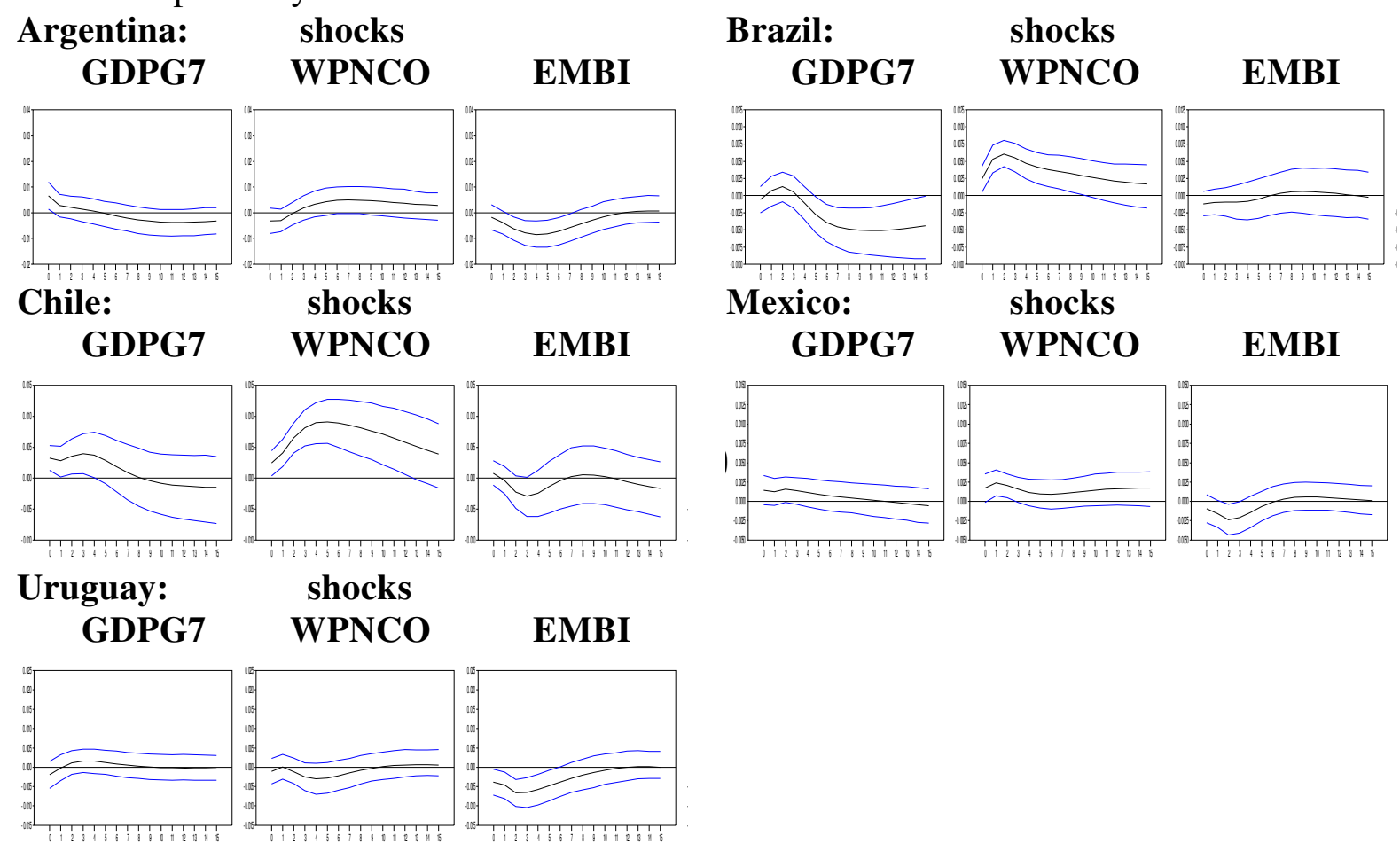

2- Credibility matters

Figures display for each country the responses of $\mathbf{R}$ and ER to CPI shocks respectively.

Argentina: Responses of $\mathbf{R}$

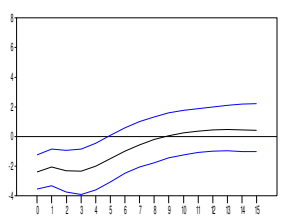

ER

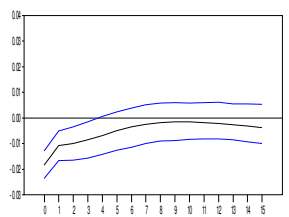

Chile : $\quad$ Responses of

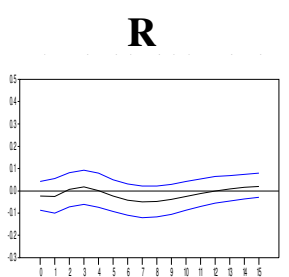

ER

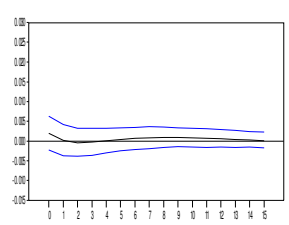

Brazil : Responses of
$\mathbf{R}$

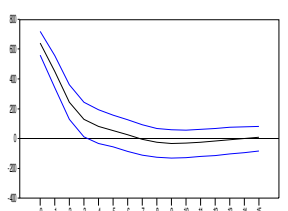

Mexico: Responses of
ER

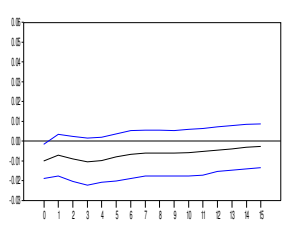

$\mathbf{R}$

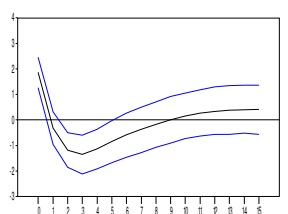

ER

Uruguay : Responses of

$\mathbf{R}$

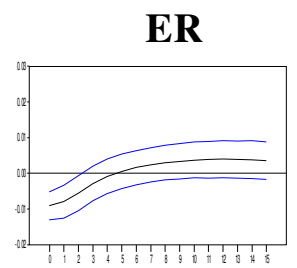


Appendix 5 Forecast Error Variance Decomposition for 16 periods, in percentage

The results display the fraction of variance in a given variable (in \%) after 16 quarters due to foreign and domestic shocks indicated in columns.

\begin{tabular}{ccccccccc}
\multicolumn{8}{c}{ Decomposition of Variance for Series GDP } \\
Argentina & 6.75 & 7.73 & 14.79 & 61.71 & 0.37 & 6.22 & 1.27 & 1.15 \\
Brazil & 26.48 & 23.48 & 0.98 & 29.89 & 7.35 & 4.67 & 0.48 & 6.68 \\
Chile & 5.26 & 39.04 & 1.57 & 31.86 & 11.22 & 2.91 & 4.31 & 3.85 \\
Mexico & 3.16 & 7.79 & 5.12 & 60.18 & 4.75 & 1.06 & 5.73 & 12.22 \\
Uruguay & 1.27 & 3.18 & 15.50 & 67.32 & 0.18 & 0.70 & 8.25 & 3.59
\end{tabular}

\begin{tabular}{ccccccccc}
\multicolumn{7}{c}{ Decomposition of Variance for Series CPI (Prices Indexes) } \\
Argentina & 11.28 & 12.88 & 2.43 & 14.91 & CPI & FOREX & R & ER \\
Brazil & 8.44 & 4.07 & 2.77 & 6.60 & 64.12 & 1.53 & 10.20 & 2.27 \\
Chile & 0.22 & 11.80 & 5.86 & 0.32 & 69.46 & 10.00 & 0.09 & 2.25 \\
Mexico & 2.42 & 0.31 & 1.49 & 3.21 & 80.15 & 11.85 & 0.13 & 0.43 \\
Uruguay & 16.01 & 31.10 & 10.04 & 6.46 & 21.63 & 1.04 & 9.05 & 4.68
\end{tabular}

\begin{tabular}{ccccccccc}
\multicolumn{8}{c}{ Decomposition of Variance for Series FOREX (Foreign Exchange) } \\
& LGDPG7 & LWCPNO & EMBI & GDP & CPI & FOREX & R & ER \\
Argentina & 2.38 & 3.09 & 15.43 & 17.72 & 3.13 & 56.73 & 1.02 & 0.49 \\
Brazil & 7.33 & 1.20 & 8.21 & 5.51 & 2.63 & 69.92 & 3.06 & 2.13 \\
Chile & 1.11 & 0.71 & 7.79 & 0.29 & 3.72 & 85.67 & 0.58 & 0.12 \\
Mexico & 5.23 & 10.76 & 0.63 & 2.42 & 14.99 & 61.79 & 3.02 & 1.15 \\
Uruguay & 2.09 & 1.41 & 1.68 & 8.49 & 0.52 & 80.88 & 2.84 & 2.09
\end{tabular}

\begin{tabular}{ccccccccc}
\multicolumn{8}{c}{ Decomposition of Variance for Series R } & (Domestic Interest Rates) \\
& LGDPG7 & LWCPNO & EMBI & GDP & CPI & FOREX & R & ER \\
Argentina & 8.79 & 2.68 & 1.28 & 4.59 & 12.79 & 1.70 & 51.94 & 16.21 \\
Brazil & 3.97 & 0.37 & 1.79 & 9.59 & 68.19 & 4.74 & 10.81 & 0.52 \\
Chile & 12.33 & 4.32 & 21.37 & 4.29 & 1.84 & 3.85 & 51.75 & 0.25 \\
Mexico & 6.59 & 4.44 & 6.98 & 6.46 & 21.35 & 8.24 & 44.31 & 1.63 \\
Uruguay & 0.78 & 0.23 & 3.19 & 2.11 & 3.77 & 2.68 & 84.78 & 2.45
\end{tabular}

\begin{tabular}{ccccccccc}
\multicolumn{8}{c}{ Decomposition of Variance for Series ER (real exchange rates) } \\
& LGDPG7 & LWCPNO & EMBI & GDP & CPI & FOREX & R & ER \\
Argentina & 2.98 & 15.99 & 1.29 & 21.42 & 12.86 & 9.24 & 8.80 & 27.41 \\
Brazil & 8.88 & 2.22 & 7.57 & 3.65 & 5.38 & 3.39 & 6.59 & 62.31 \\
Chile & 4.72 & 7.82 & 4.09 & 2.11 & 0.78 & 3.63 & 0.82 & 76.04 \\
Mexico & 0.34 & 3.05 & 2.17 & 3.44 & 21.87 & 4.74 & 17.43 & 46.96 \\
Uruguay & 8.12 & 2.55 & 13.32 & 15.14 & 7.84 & 8.02 & 1.88 & 43.13
\end{tabular}

